Original Article

Received/Accepted

Dates

$01.11 .2021 / 05.12 .2021$

DOI 10.52096/usbd.5.23.5.20
International Journal of Social Sciences Uluslararası Sosyal Bilimler Dergisi

www.sobider.net
ISSN: 2548-0685

\title{
Fransız Milletlerarası Tahkim Kanunu’nun İncelenmesi
}

Aynaz UĞUR

\author{
Marmara Üniversitesi SBE Doktora Öğrencisi
}

aynazugur@gmail.com

ORCID ID: 0000-0003-1934-1051

\section{Özet}

Milletlerarası ticari tahkim terimi, milli tahkimden farklı olarak, "ticari" olma ve "milletlerarası" nitelik taşıma özelliklerini birlikte barındırmaktadır. Milletlerarası olma kriteri, en geniş yorumuyla, Fransız Tahkim Kanunu'nun içinde yer aldığı eski Fransız CPC m. 1492 hükmü ile düzenlenmişti. 13 Ocak 2011 reformu ile de korunan bu düzenleme uyarınca; milletlerarası ticari menfaatlere ilişkin tahkim, milletlerarasıdır. Fransız Tahkim Komitesi 1992 yılında “Fransız Tahkim Hukuku’nun İyileştirilmesi Hakkında Perspektifler” isimli bir rapor hazırlamıştı. 13 Ocak 2011 Kararnamesi ile yapılan değişiklik ne bir devrim ne de basit bir makyaj olup; açıklık, belirlilik, esneklik, irade özerkliği, etkinlik ve hızlılık kelimeleriyle özetlenebilecek olan gerçek bir reformdur. 2011 reformu Fransız Milletlerarası Tahkim Hukuku'nun temelini oluşturan; sözleşme özgürlügüne dayanan ve yalnızca uluslararası kamu düzeni ile sınırlandırılmış olan liberal yapıyı değiştirmemiştir.

Anahtar Kelimeler: Fransa, Milletlerarası Tahkim, İrade Özerkliği, Kamu Düzeni, Liberal.

\section{Analysis of French International Arbitration Code}

\begin{abstract}
International arbitration notion contains to be commercial and to be international together, different from national arbitration notion. To be international criterion is to the fullest extent arranged in old French CPC art. 1492, which contains also French Arbitration Code. According to this article which is protected by 13
\end{abstract}


January 2011 reform; arbitration which is about international commercial benefit is an international arbitration. In 1992 French Arbitration Commitee prepared a report with the name of "Perspectives for İmprovement of French Arbitration Law". The amendements of the directive of 13 January 2011 is neither a revolution nor an easy make up but it is a real reform which can be known as by the words clarity, definiteness, flexibility, freedom of choice, effectuality and speediness. The reform of 2011 did not changed the liberal structure of the French international arbitration law which is stand by freedom of contract and limited only by public policy.

Keywords: France, International Arbitration, Freedom of Choice, Public Policy, Liberal

\section{Giriş}

Tahkim, kanunun tahkim yoluyla çözülmesine izin verdiği konular kapsamında olmak koşuluyla, taraflar arasında doğmuş ve doğabilecek uyuşmazlıkların devlet yargısında çözümlenmesi yerine, hakem adı verilen kimseler aracılığı ile nihai ve bağlayıcı olarak çözümlenmesi konusunda tarafların anlaşmaları şeklinde tanımlanabilir ${ }^{1}$. Milletlerarası ticari tahkim terimi, milli tahkimden farklılı̆̆ 1 belirlemek ve buna göre farklı kuralları esas almak adına tahkimde "ticari”" olma ve "milletlerarası" nitelik taşıma özelliklerini birlikte barındırmaktadır². Milletlerarası olma kriteri, en geniş yorumuyla, Fransız Tahkim Kanunu'nun içinde yer aldığı eski Fransız CPC ${ }^{3}$ m. 1492 hükmü ile düzenlenmişti. 13 Ocak 2011 reformu ile de korunan bu düzenleme uyarınca; milletlerarası ticari menfaatlere ilişkin tahkim, milletlerarasıdır ${ }^{4}$.

Fransız Tahkim Hukuku 14 Mayıs 1980 tarihli Kararname ile iç tahkim bakımından; 12 Mayıs 1981 tarihli Kararname ile de milletlerarası tahkim bakımından ivme kazanmıştır. Milletlerarası tahkime ilişkin 1981 tarihli reformun özellikleri; milletlerarası tahkimin, konu edindiği işlemlerin ekonomik nitelikte olması, taraflarının hukuki durumlarını ve milliyetleri gibi kriterleri göz önünde bulundurmuş olması; tahkim prosedürüne ve uyuşmazlığın esasına uygulanacak hukuk

\footnotetext{
${ }^{1}$ Akıncı Ziya, Milletlerarası Tahkim, 6. Baskı, Vedat Yayınevi, İstanbul, 2021, s. 29; Robert Jean, L'Arbitrage, 6. Bask1, Éditions Dalloz, Paris 1993, s. 3.

${ }^{2}$ Özel Sibel, Milletlerarası Ticari Tahkimde Kanunlar İhtilafı Meseleleri, 1. Baskı, Legal Yayınevi, İstanbul 2008, s. 19.

3 Code de Procédure Civil 1808 avec les amendement adoptés en 13 Janvier 2011, http://www.legifrance.gouv.fr/affichCode.do?cidTexte=LEGITEXT000006070716,
}

${ }^{4}$ Özel, s. 22. 
hakkında düzenlemeler getirirken taraf iradelerine üstünlük tanıması ve başvuru yollarını basit ve sınırlı bir konseptte tanıması şeklinde özetlenebilir 5 .

Fransız Tahkim Kanunu birçok ülkenin milletlerarası tahkim düzenlemelerine bakıldığında iyi işleyen bir durumdayd ${ }^{6}$. Ancak yine de reforma ihtiyaç duyulmuş olmasının temelde iki sebebi vardı: Öncelikle Fransız Tahkim Hukuku artık oldukça içtihadi bir hal almıştı ve bu da yabancı uygulamacılar açısından zorluk yaratıyordu ${ }^{7}$. İkinci sebep de neticede otuz yıl önce getirilmiş düzenlemelerin günümüz koşullarına uyarlanmasında güçlük çekilmesiydi.

Fransız Tahkim Komitesi 1992 yılında “Fransız Tahkim Hukuku'nun İyileştirilmesi Hakkında Perspektifler" isimli bir rapor hazırlamıştı. 13 Ocak 2011 Kararnamesi ile yapılan değiş̧iklik ne bir devrim ne de basit bir makyaj olup; açılık, belirlilik, esneklik, irade özerkliği, etkinlik ve hızlılık kelimeleriyle özetlenebilecek olan gerçek bir reformdur.

2011 reformu Fransız Milletlerarası Tahkim Hukuku'nun temelini oluşturan; sözleşme özgürlüğüne dayanan ve yalnızca uluslararası kamu düzeni ile sınırlandırılmış olan liberal yapıyı değiştirmemiştir?. Başbakanlık Raporu'nda, kamu tüzel kişilerinin milli hukuklarını gerekçe göstererek tahkim anlaşmasına karşı koyamayacakları hükmüne yer veren ünlü "Galakis Kararı'na""; milletlerarası bir kararın hiçbir hukuk düzenine "bağlı sayılamayacağı" ifadesini içeren "Putrabali Kararı'na"11 ve aynı durum için "entegre olmak" deyiminin tercih edildiği "Hilmarton Kararı'na"12 değinilmiştir ${ }^{13}$. Milletlerarası tahkim ve iç tahkim ayrımına dayanan ikili yaklaşım bu reform ile de korunmuştur ${ }^{14}$.

Fransız Tahkim Kanunu'nu inceleyeceğimiz çalışmamızda, başlangıçta yer alan milletlerarası ticari tahkim tanımlaması hükmü ve danışman hakime ilişkin düzenlemenin ardından tahkim

\footnotetext{
${ }^{5}$ De Boisséson Matthieu, Le Droit Français De L’Arbitrage Interne Et International, GLN- Éditions, 1990, s. 465, 466.

${ }^{6}$ Fortier L. Yves, “La Nouvelle Loi Française Sur L'Arbitrage: Vues D’Outre Atlantique”, Fransız Tahkim Kurumu (Association Française D’Arbitrage) Y1llık Konferansı Tebliğ Metni, 28 Eylül 2011, Paris, s. 2.

${ }^{7}$ Gaillard Emmanuel / De Lapasse Pierre, "Le Nouveau Droit Français De L'Arbitrage Interne Et International", Etudes Et Commentaires Chroniques / Arbitrage, Recueil Dalloz, 20 Janvier 2011, Numéro 3, s. 176.

${ }^{8}$ Jarrosson Charles / Pellerin Jacques, "Le Droit Français De L'Arbitrage Aprés Le Décret Du 13 Janvier 2011", Revue De L'Arbitrage, S. 1, Ocak-Mart, 2011, s. 6, (Rev. Arb.).

${ }^{9}$ Jarrosson / Pellerin, s. 55; Fortier, s. 14.

${ }^{10}$ Cass. Civ. 1re, 02.05.1966, Rev. Arb., 1966.99.

${ }^{11}$ Cass. Civ. 1re, 29.06.2007, Rev. Arb., 2007.507.

${ }^{12}$ Cass. Civ. 1re, 23.03.1994, Rev. Arb., 1994.327.

${ }^{13}$ Jarrosson / Pellerin, Rev. Arb., s. 55.

${ }^{14}$ Fortier, s. 4.
} 
anlaşması, tahkim davası ve hakem kararı, hakem kararlarının tanınması ve tenfizi ve başvuru yolları bölümlerine yer verirken; eski Fransız Tahkim Kanunu'ndan da yeri geldikçe bahsedecek, gerektiğinde UNCITRAL Model Kanunu ve TMTK ile de kıyaslamalar yapacağız.

\section{Başlangıç Hükümleri}

\section{A. Milletlerarası Ticari Tahkim Kavramının}

Fransız Kanunu Bakımından Değerlendirilmesi

\section{Ticari Olma Kriteri}

Uncitral Model Kanunu'nun ${ }^{15}$ 1. Maddesi, bu Kanun'un milletlerarası ticari tahkime uygulanacağının ifade etmiş ancak ticari deyiminin tanımını vermemiştir. Madde’nin dipnotunda, ticari terimi bir sözleşmeye ilişkin olan veya olmayan ticarete dayalı her türlü ilişkiden doğabilecek konuları kapsaması bakımından geniş bir çerçevede yorumlanmalıdır ifadesine yer verilmiş ve ticari nitelikli ilişkiler tahdidi olmamak üzere örneklendirilmiştir ${ }^{16}$.

New York Konvansiyonu da muamelelerin ticari niteliğine atıf yapmış, m. 1/b. 3 hükmünde her akit devletin kendi milli hukukuna göre ticari mahiyette olan uyuşmazlıklar için bu sözleşmeyi uygulayacağına dair çekince koyabileceğini öngörmüştür ${ }^{17}$. Fransa da yorum hususundaki güçlükler sebebiyle başlangıçta bu çekinceyi koymuş ${ }^{18}$ ancak sonradan geri çekmiştir ${ }^{19}$.

Fransa da diğer birçok Kıta Avrupası ülkesi gibi ticari-ticari olmayan iş ayrımı yapan bir ülkedir. Fransa ticari olma kriterini Uncitral Model Kanunu'na uygun şekilde geniş yorumlamaktadır. İşlemin ticari olması kriteri, aşağıda daha ayrıntılı işleyecek olduğumuz milletlerarası olma

\footnotetext{
${ }^{15}$ La Loi Type De La CNUDCI Sur L'arbitrage Commercial International, tell qu'adoptée par le Commission des Nations Unies Pour Le Droit Commercial International le 21 Juin 1985 et amendée par elle le 7 Juillet 2006, http://www.uncitral.org/pdf/french/texts/arbitration/ml-arb/07-86999_Ebook.pdf

${ }^{16}$ Dayınlarlı Kemal, International Arbitration, Dayınlarlı Yayınları, Ankara 2010, s. 97, 98, (Arbitration).

17 New York Convention Pour La Reconnaissance Et L'Execution Des Sentences Arbitrales Etrangeres, tell qu'adoptée en 1958, http://www.uncitral.org/pdf/french/texts/arbitration/NY-conv/XXII_1_f.pdf

${ }^{18}$ De Boisséson, s. 420.

${ }^{19}$ Özel, s. 21.
} 
kriterinde de olduğu gibi, milletlerarası ticaretin menfaatlerini ilgilendirmeye bağlı ve ekonomik nitelik taşıyan bütün işlemleri kapsayıcı şekilde açıklanmakta ${ }^{20}$; mal ve hizmet tedarik ya da değişimi ile üretim faaliyetleri ve inşaat işleri örnek verilmektedir ${ }^{21}$. Aynı düzenleme eski CPC m. 1492 hükmünde yer alıyordu.

TMTK m. 2 hükmünün yabancılık unsurunu tanımlayan düzenlemesinde, uyuşmazlığa nelerin yabancılık unsuru kattığı sayılmıştır. Hükmün 4. bendinde ifade edilen, "tahkim anlaşmasının dayanağını oluşturan asıl sözleşme veya hukuki ilişkinin, bir ülkeden diğerine sermaye veya mal geçişini gerçekleştirmesi” şartı, milletlerarası ticarete ilişkin neredeyse her şeyi içine alacak düzeyde geniş bir düzenleme olup; "milletlerarası ticaretin menfaatlerini ilgilendirme" kriterine benzetilebilir ${ }^{22}$.

\section{Milletlerarası Olma Kriteri}

CPC m. 1504 hükmü uyarınca, milletlerarası ticari menfaatlere ilişkin tahkim milletlerarasıdır. Tahkim milletlerarası niteliğini uyuşmazlık konusunun ekonomik etkilerinden almaktadır ${ }^{23}$.

Fransız Tahkim Hukuku, milletlerarası olma kriterinin tespitinde temeldeki muameleye odaklanmış ve objektif kriterin en geniş yorumuyla uygulandığı ülkedir ${ }^{24}$. Buna göre tarafların milliyeti, sözleşmeye ya da tahkime uygulanacak hukuk ya da tahkim yeri ne olursa olsun, milletlerarası ticaretin menfaatleri söz konusu olduğunda ya da temeldeki sözleşme; yani uyuşmazlık konusu milletlerarası nitelik taşıdığında, tahkimin milletlerarası nitelik kazandığı kabul edilecektir ${ }^{25}$.

${ }^{20}$ Robert, s. 228.

${ }^{21}$ De Boisséson, s. 421.

${ }^{22}$ Akınci, s. 66.

${ }^{23}$ Robert, 227; Dayınlarlı, Arbitration, s. 98.

24 Özel, s. 22.

${ }^{25}$ Jarrosson / Pellerin, Rev. Arb., s. 58; De Boisséson, s. 425. 
Fransız Yargitay’1 Mardelé ${ }^{26}$ ve Dambricourt ${ }^{27}$ Kararları'nda tarafların ikisi de Fransız uyruğunda olmalarına rağmen, uyuşmazlığın milletlerarası ticaretin menfaatlerini ilgilendirdiği gerekçesini açıkça ifade ederek, tahkimin milletlerarası niteliğine hükmetmiştir.

Model Kanun'daki milletlerarası tahkim tanımı objektif ve sübjektif kriterleri birlikte bünyesinde barındıran, modern karma kriteri temel almıştır ${ }^{28}$. Karma kriteri esas alan diğer bir Kanun da TMTK'dır' ${ }^{29}$. TMTK m.2 hükmüne göre, Kanun'da sayılan hallerden birinin varlığı halinde yabancılık unsurunun olduğu kabul edilir ve bu durumda tahkim milletlerarası nitelik taşır. Burada ayrıca m.2/b.4 hükmünün tahkime milletlerarası nitelik verme konusunda uygulama alanı en geniş olan hüküm olarak altını çizmek gerekir ${ }^{30}$. Yabancılık unsurunu oluşturan haller sayılırken genelde ekonomik nitelikli ilişkilere atıf yapılmış; ancak tarafların yerleşim yeri, işyeri, tahkim yeri, uyuşmazlık konusunun en çok bağlantılı olduğu yer gibi kriterlere de yer verilmiştir.

\section{B.Danışman Hakim Uygulaması}

CPC m. 1505 hükmü şöyledir:

“(1) Tahkim Fransa’ da görülürse,

(2) Taraflar tahkimi Fransız Tahkim Kanunu'na tabi kılmada anlaşmışlarsa,

(3) Taraflar tahkim usulüne ilişkin ihtilafları yargılamak için Fransız devlet mahkemelerine açıkça yetki vermişlerse veya

(4) Taraflardan biri hak kaybına uğrama riski açıklamışsa;

milletlerarası tahkim konusunda, tahkim usulünün danışman hakimi, aksi kararlaştırılmadıkça, Paris Asliye Hukuk Mahkemesi Başkanı'dır.”.

${ }^{26}$ Cas. Civ. 19.02.1930, (De Boisséson, s. 425).

${ }^{27}$ Cas. Civ. 27.01.1931, (De Boisséson, s. 425).

${ }^{28}$ Özel, s. 23.

${ }^{29}$ Özel, s. 24.

${ }^{30}$ Akıncı, s. 66. 
Bu hüküm tahkim yerinin Fransa dışında belirlendiği hallerde, yerel bazı düzenlemelerin Fransız Usul Kanunu ile çatışması halinde bir tür uzlaştırma yolu olarak işe yaramaktadır ${ }^{31}$. Ancak özellikle b.3 hükmünün gerçekleştiği durumlarda yabancı ülkede alınmış bir kararın kontrolü direkt Fransız hakimine bırakıldığından, yabancı hakim ile Fransız hakimi arasında bir yetki çatışması doğabilirr ${ }^{32}$.

CPC m. 1505/b.4 hükmündeki "hak kaybına uğrama riski” ifadesi muğlak bir düzenleme olduğundan eleştirilmektedir. Ancak bu Fransız Hukuku'nda yeni kullanılan bir ifade değildir. Fransız Yargitayı State of Israel v. National Iranien Oil Company Kararı'nda bu durumu, taraflarda birinin, diğerinin hakkını yerine getirmesini etkin bir şekilde bloke etmesi şeklinde tanımlamışıı ${ }^{33}$. Hükmün karşıllğı eski CPC m. 1493/2 düzenlemesidir. Buna göre Fransa'da yürütülen ya da tarafların Fransız Kanunu'nun uygulanmasını öngördüğü tahkimler için tahkim mahkemesinin teşkilinde bir güçlükle karşılaşılırsa, aksine düzenleme olmadıkça, önce hareket eden taraf, Paris Asliye Hukuk Mahkemesi Başkanı’nı yetkili kılabilir. Görüldüğü üzere 2011 reformu ile Paris hakimi danışman hakim sıfatıyla daha geniş ve farklı yetkilerle donatılmış ve durum sadece tahkim mahkemesinin teşkil edememiş olması ile sınırlı olmaktan çıkarılmışıır³ ${ }^{34}$ TMTK böyle bir düzenleme içermemektedir.

\section{III.Tahkim Anlaşması}

\section{A.Tanım}

CPC'deki milletlerarası tahkim bölümünde tahkim anlaşması tanımlanmamış; iç tahkim bölümünün bazı hükümlerine atıf yapan m. 1506 düzenlemesinde de, tahkim anlaşmasını tanımlayan m. 1442 hükmüne atıf yapılmamıştır.

Bu hükümde, tahkim anlaşması tahkim şartı ya da tahkim sözleşmesi şeklinde olur denilerek; ikili bir ayrıma gidilmiştir. Tahkim şartı ifadesi doğabilecek uyuşmazlıklar için, tahkim sözleşmesi

\footnotetext{
${ }^{31}$ Jarrosson / Pellerin, Rev. Arb., s. 59.

32 Jarrosson / Pellerin, Rev. Arb., s. 59.

${ }^{33}$ Lin Yu Hong / Ahmed Masood, "The New French Arbitration Law: An Analysis", International Arbitration Law Rewiev, 2012, s. 23, (I.A.L.R).

${ }^{34}$ Gaillard / De Lapasse, s. 186.
} 
ifadesi ise hali hazırda doğmuş bir uyuşmazlık için kullanılıyordu ${ }^{35}$. Milletlerarası tahkim bakımından bu ayrımın kaldırıldığı söylenebilir ${ }^{36}$.

CPC'nin eski halinde, uluslararası tahkimi düzenleyen bölümdeki m. 1495 hükmünün iç tahkim düzenlemelerine yaptığı atıf gereği; tahkim şartını düzenleyen m. 1442 hükmü ve tahkim sözleşmesini düzenleyen m. 1447 hükmü uygulanıyordu. Yani söz konusu ayrım milletleraras1 tahkim için de geçerliydi.

Gerek Model Kanun'da gerekse TMTK'da tahkim anlaşması benzer şekilde tanımlandıktan sonra, tahkim anlaşmasının tahkim şartı ya da ayrı bir anlaşma şeklinde yapılabileceği hükme bağlanmış; ancak Fransız iç tahkim düzenlemesinde olduğu gibi teknik bir ayrıma gidilmemiştir ${ }^{37}$. Neticede ikisi de aynı hukuki etkiye sahiptir.

\section{B.Tahkim Anlaşmasının Bağımsızlığı}

Tahkim anlaşmasının bağımsızlığını CPC'deki Milletlerarası Tahkim Bölümü’nün 1506. Maddesi'nin, İç Tahkim Bölümü’ndeki 1447. Madde’ye yaptığı atıf sağlamaktadır. Buna göre tahkim anlaşması, ait olduğu sözleşmeden bağımsızdır, sözleşmenin geçersiz oluşundan etkilenmez ${ }^{38}$.

Gosset Kararı'ndan beri, tahkim anlaşmasının asıl sözleşmeden bağımsızlığı, milletlerarası özel hukukun temel ilkesi olarak kabul edildi ${ }^{39}$. Menicucci c./ Mahieux Kararında ise ayrıca tahkim anlaşmasının tüm devlet hukuklarına göre bağımsızlığı ortaya kondu ${ }^{40}$. Hecht Kararı'nda ise

\footnotetext{
${ }^{35}$ Jarrosson / Pellerin, Rev. Arb., s. 62; De Boisséson, s. 475; Guinchard Serge / Ferrand Frédérique, Procédure Civil, 28e Édition, Dalloz, Paris 2006, s. 1352.

${ }^{36}$ Gaillard / De Lapase, s. 184.

${ }^{37}$ Akıncı, s. 80; Dayınlarlı Kemal, UNCITRAL Kurallarına Göre Uzlaşma Ve Tahkim, 3. Baskı, Dayınlarlı Hukuk Yayınları, Ankara 2012, s. 167, (Uncitral).

${ }^{38}$ Lin Yu / Ahmed, I.A.L.R., s. 20.

${ }^{39}$ Cass. Civ., 7.05.1963, (Rev. Arb., s. 63); Poudret Jean François, “L’Originalité de Droit Français De L'Arbitrage Au Regard Du Droit Comparé", Revue Internationale De Droit Comparé, Année 2004, Volume 56, Numéro 1, s. 135, (R.I.D.C.)

${ }^{40}$ De Boisséson, s. 493; Poudret, R.I.D.C., s. 136.
} 
Fransız Hukuku açısından tahkim anlaşmasının bağımsızlığının sınırlarını Fransız Hukuku'nun emredici kuralları ve kamu düzeni şeklinde çizilmiştir ${ }^{41}$.

Aynı düzenleme UNCITRAL Model Kanunu m. 16(1) hükmünde ve TMTK m. 4 hükmünde de kabul edilmiştir ${ }^{42}$.

\section{C.Tahkim Anlaşmasının Şekli}

CPC m. 1507 hükmüne göre, milletlerarası tahkimde, tahkim anlaşması hiçbir şekil şartına tabi değildir ${ }^{43}$. İç tahkimde ise yazılı şekil şartı aranmaktadır. CPDC’nin bundan önceki düzenlemesinde m.1495 hükmü uluslararası tahkim Fransız Kanunu’na tabi olduğu zaman, bu Kanun'un I., II., ve III. Bap hükümleri (yani iç tahkim hükümleri), taraflar aksine bir düzenleme yapmamışlarsa uygulanır şeklindeydi. Bu şartlar altında m. 1443 uyarınca tahkim şartının ve m. 1449 uyarınca tahkim sözleşmesinin yazılı olması gerekir. Ancak taraflar aksini kararlaştırabildiğinden ve yazılı şekil şartını düzenleyen hükümlere yalnızca uluslararası tahkimin Fransız Kanunu'na tabi kılınması hali için atıf yapıldığından, Fransız Tahkim Hukuku'nda tahkim anlaşmasının yazılı şekil şartına tabi olmadığı sonucuna geçmiş uygulama döneminde de varılıyordu $^{44}$. Ancak tahkim şartı bakımından aksi görüşü savunmuş olanlar da vardır ${ }^{45}$.

Tahkim anlaşmasının sözlü şekilde yapılması, tanıma ve tenfiz aşamasında tahkim anlaşmasının delil olarak devlet mahkemelerince talep edilmesi halinde sorun yaratabilmektedir ve bu nedenle iki hükmü birbiriyle çelişkili bulan görüşler mevcuttur ${ }^{46}$. Ancak Fransa'da tahkim anlaşmasına dayanarak tanıma ve tenfiz talep eden taraf anlaşmayı başka delillerle ispatlayabildikten sonra ve hakem kararı kamu düzenine aykırı değilse, talep kabul edilmektedir ${ }^{47}$. Bu durum özellikle

\footnotetext{
${ }^{41}$ De Boisséson, s. 494; Poudret, R.I.D.C., s. 135.

${ }^{42}$ Akıncı, s. 90; Özel, s. 37.

${ }^{43}$ Gaillard / De Lapase, s. 184.

${ }^{44}$ De Boisséson, s. 477; Poudret, R.I.D.C., s. 137.

${ }^{45}$ Guinchard / Ferrand, s. 1361.

${ }^{46}$ De Boisséson, s. 478; Lin Yu / Ahmed, I.A.L.R., s. 20, 21.

${ }^{47}$ Lin Yu Hong, “Written Arbitration Agreements-What Written Arbitration Agreement?", Civil Justice Quarterly, 2013, 32(1), s. 84, (C.J.Q.).
} 
Fransa'da verilen bir hakem kararının, tenfiz aşamasında sıkı şekil şartları arayan bir başka ülkede tenfizi gündeme geldiğinde sorun yaratabilmektedir ${ }^{48}$.

Fransız Hukuku'ndaki bu liberal uygulama, tahkim hukukunun ve milletlerarası ticaretin genel anlamda lehine olsa da, New York Konvansiyonu m.2 hükmü karşısında ciddi bir farklılık yaratmıştır $^{49}$. Yazılı şekil şartı, son teknolojik imkanları da içine alır şekilde, çok geniş yorumlanmakla birlikte, Model Kanun'da da korunmaktadır ${ }^{50}$. Aynı düzenleme TMTK'da da mevcuttur 51 .

\section{IV.Tahkim Davası Ve Hakem Kararı}

\section{A.Tahkim Usulü}

CPC m. 1509 hükmü uyarınca; tahkim anlaşması, doğrudan doğruya veya bir tahkim tüzüğüne veya usul kurallarına atıfta bulunarak, tahkim davasında takip edilecek usulü düzenleyebilir. Tahkim anlaşmasının sessiz kalması halinde, tahkim usulünü, ihtiyaç duyduğu takdirde, ya doğrudan doğruya ya da bir tahkim tüzüğüne veya usul kurallarına atıfta bulunarak, hakem heyeti düzenler.

Görüldüğü gibi taraflar tahkim usulüne uygulanacak hukukun seçimi hususunda serbest bırakılmışlar; ancak sözleşmede bir seçim yapmamışlarsa seçimi hakem heyetinin yapması hususu öngörülmüştür. Hakem heyeti ihtiyaç duyması halinde bir tahkim tüzüğünü ya da usul kurallarını uygulayabilecek ya da usul kurallarını doğrudan doğruya kendisi belirleyebilecektir. Buradaki "usul kuralları" ifadesi, tarafları kurumsal tahkim kurallarıyla ya da bir usul kanunuyla sınırlanmayacak şekilde geniş yorumlanmalıdır ${ }^{52}$. Bu anlatımla taraflar hukuk kuralları yerine davranış kurallarını da seçmekte serbesttirler ${ }^{53}$.

\footnotetext{
${ }^{48}$ Lin Yu / Ahmed, I.A.L.R., s. 21.

${ }^{49}$ Jarrosson / Pellerin, Rev. Arb., s. 64; De Boisséson, s. 478.

${ }^{50}$ Dayınlarlı, Uncitral, s. 167.

${ }^{51}$ Akinci, s. 90.

${ }^{52}$ Jarrosson / Pellerin, Rev. Arb., s. 66.

53 Özel, s. 98.
} 
2011 reformundan önceki dönemde de CPC m. 1494 gereği taraf iradelerine öncelik veriyor, onların bu hususu boş bırakmaları halinde aynı yetkiyi hakemlere tanıyordu ${ }^{54}$.

1899 yılından beri Fransız Yargıtay'ı tahkime uygulanacak hukuk konusunda tarafların serbestçe karar verebilmelerini kabul etmektedir ${ }^{55}$. Ayrıca 8 Aralık 1914 tarihli Salles c./Hale Kararı ve 27 Temmuz 1937 tarihli Roses Moller Kararı da önemli örneklerdendir ${ }^{56}$.

Uncitral Model Kanunu da m.19 hükmünde taraflara aynı serbestiyi tanımakta ve tarafların susması halinde hakem heyetini yetkilendirmekte olup; tarafların seçim hakkını Model Kanun'un emredici hükümleriyle, hakemlerinkini ise Model Kanun'un tüm hükümleriyle sınırlamıştı5 ${ }^{57}$.

TMTK m. 8 hükmü de taraflara aynı serbestiyi tanımış, ancak TMTK'nın emredici hükümlerine aykırı düzenleme yapamayacaklarını hükme bağlamışıır ${ }^{58}$. Ancak CPC'den farklı olarak hakemlere uygulanacak usulü belirleme yetkisi vermeyerek; tarafların tahkim usulüne ilişkin herhangi bir hükme yer vermemeleri durumunda, tahkim usulüne TMTK hükümlerinin uygulanacağını düzenlemiştir ${ }^{59}$.

\section{B.Usuli Kamu Düzeni}

CPC m. 1510 hükmüne göre, seçilen usul ne olursa olsun, hakemler tarafların eşitliğini garanti eder ve silahların eşitliği prensibine riayet eder ${ }^{60}$. CPC'nin iç tahkim hükümlerine atıf yapan 1506. Madde'sinde, CPC'nin genel emredici usul ilkerine atıf yapan iç tahkim hükmü olan m. 1464/b.2 hükmüne atıf yapılmamıştır. Bu durum söz konusu hükümlerin milletlerarası tahkimde geçerli olup olmayacağ1 sorununu gündeme getirmiştir. Ancak böyle bir karşıt yoruma meyledilmemesi gerektiği savunulmakta, uluslararası mevzuların CPC'nin uygulanmasını engellememesi gerektiği ifade edilmektedir ${ }^{61}$.

\footnotetext{
${ }^{54}$ Robert, s. 259; De Boisséson, s. 653; Özel, s. 98.

${ }^{55}$ De Boisséson, s. 653.

${ }^{56}$ De Boisséson, s. 654.

${ }^{57}$ Dayınlarl, Uncitral, s. 173.

${ }^{58}$ Akıncı, s. 121; Özel, s. 101.

${ }^{59}$ Akıncı, s. 123; Özel, s. 101.

${ }^{60}$ Fortier, s. 11.

${ }^{61}$ Jarrosson / Pellerin, Rev. Arb., s. 66.
} 
Fransız Yargıtay'1 2007 tarihli Putrabali Kararı'nda, Fransız uygulamasında yeni olmamakla birlikte hakem kararının devletin hukuk düzenine entegre olmayacağı ilkesinin altını çizdikten sonra, yabancı hakem kararın ifade etmek için "une décision de justice international" / "decision of international justice" deyimine ilk kez yer vermiştir ${ }^{62}$. Hakem kararının uluslararası yargılama / juridiction internationale / international juridiction neticesinde elde edildiği imajı veren bu Karar'daki yeni kavram, tahkim hukukunun genel teorisine dayanıyordu ${ }^{63}$. Ancak 2011 reformunda bu yeni yaklaşıma yer verilmedi ${ }^{64}$.

Tarafların yabancı hukuk seçimi yapmaları ya da kurumsal tahkim kurallarına atıf yapmaları halinde, iç tahkim uygulamasında geçerli olan, hakem kararının gerekçeli olması veya imza zorunluluğu gibi hususlar aranmaz ${ }^{65}$.

Eski CPC düzenlemesinde açık bir kamu düzeni hükmüne yer verilmemiş; ancak tanımaya ilişkin m. 1498 hükmünde ve tanıma ve tenfizi kabul edilen kararın istinafına ilişkin m. 1502/b.5 hükmünde "uluslararası kamu düzeni" kavramı açıkça ifade edilmiştir. Tanıma ancak uluslararası kamu düzenine aykırılık teşkil etmiyorsa yapılabilmekte; tanıma ve tenfiz uluslararası kamu düzenine aykırı ise istinafı mümkün olmaktadır ${ }^{66}$. Bu hallerde iç kamu düzeninin bir müdahalesi yoktur.

Yabancı ülkede verilmiş bir hakem kararının Fransa'da tanınması ve tenfizinde Fransız iç kamu düzeninin müdahalesi söz konusu olmaz; fakat bu kararda taraflar tahkimi Fransız kanunlarına tabi kılmışlarsa, bu takdirde hakemler, Fransız Hukuku'nun emredici kurallarına uymak zorundadirlar ${ }^{67}$.

New York Konvansiyonu m.5/b.2b uyarınca da, hakem kararının tanınması ve tenfizi o ülkenin kamu düzenine aykırılık teşkil ediyorsa, talep reddedilir. Uncitral Model Kanunu da "taraflara eşit muamele" başlığı altında CPC ile aynı hükmü düzenlemiştir ${ }^{68}$.

\footnotetext{
${ }^{62}$ Gaillard Emmanuel, "La Jurisprudence De La Cour De Cassation En Matière D'Arbitrage International”, Fransiz Yargitayı'na Sunulan Tebliğ Metni, 13.03.2007, s. 3; Fortier, s. 15.

${ }^{63}$ Gaillard, s. 3.

${ }^{64}$ Fortier, s. 15.

${ }^{65}$ Poudret, R.I.D.C., s. 145; Dayınlarlı Kemal, Milli-Milletlerarası Kamu Düzeni Tahkime Etkileri Ve Sonuçları, 2. Bask1, Dayınlarlı Yayınları, Ankara 2011, s. 132, (Kamu Düzeni).

${ }^{66}$ Dayınlarl, Kamu Düzeni, s. 131; Robert, s. 284, 285.

${ }^{67}$ Dayınlarlı, Kamu Düzeni, s. 132, 133.

${ }^{68}$ Dayınlarl, Arbitration, s. 104.
} 
TMTK m.8/(B) hükmü de tarafların eşitliğine ilişkin aynı düzenlemeyi içerir ${ }^{69}$. Kamu düzenine aykırılık TMTK m.15/(A)/2/b uyarınca yabancı hakem kararının iptali sebebidir.

\section{C.Hakem Mahkemesinin Kendi Yetkisi Hakkında Karar Vermesi}

Milletlerarası tahkimde tahkim sözleşmesinin temeldeki sözleşmeden bağımsız oluşu, hakem heyetinin yargılama yetkisi konusunda bizzat kendisinin karar vermesi ilkesine yol açmıştı ${ }^{70}$. CPC m. 1506 hükmünün iç tahkime ilişkin m. 1465 hükmü uyarınca, hakem mahkemesinin kompetenzkompetenz yetkisinden bahsedilebilir. Hükme göre, kendi yargı yetkisine ilişkin itirazlar üzerine karar vermek için hakem mahkemesi tek yetkilidir.

Fransız Hukuku'nda kompetenz-kompetenz yetkisi, bazı ülkelerden farklı olarak prensibin negatif etkisini de tanımaktadır. Buna göre hakem heyeti kendi yetkisi hakkında karar vermeden devlet mahkemeleri tahkim sözleşmesinin varlığı ve geçerliliği ile ilgili hiçbir mesele hakkında karar vermeyecektir ${ }^{71}$.

Eski CPC hükmünün m. 1466 hükmü de aynı durumu düzenliyordu. Uncitral Model Kanunu m. 16/(1)'de de aynı düzenleme mevcuttur ${ }^{72}$. Hakem heyeti başlangıç ve ön yetki olarak kendi yetkisini belirleme hakkına sahiptir. Bu yönde verdiği karar hakem kararının iptali davasında veya tenfiz aşamasında devlet mahkemesinin kontrolünden geçmektedir ${ }^{73}$. TMTK m.7/(H) düzenlemesi de aynı yöndedir ${ }^{74}$.

\section{D.Geçici Hukuki Korumalar}

CPC'de geçici hukuki koruma tedbirleri de m. 1506 hükmünde iç tahkim hükümlerinden m. 1449'a atıf yapılarak düzenlenmiştir. Buna göre hakem mahkemesi teşekkül edilmemişse, bir

\footnotetext{
${ }^{69}$ Akıncı, s. 123, 124.

70 Özel, s. 102.

${ }^{71}$ Özel, s. 107; Poudret, R.I.D.C., s. 142; Lin Yu / Ahmed, I.A.L.R., s. 21.

${ }^{72}$ Dayınlarl, Arbitration, s. 103.

${ }^{73}$ Dayınlarlı, Uncitral, s. 171; Özel, s. 107.

${ }^{74}$ Özel, s. 109.
} 
tarafın soruşturma önlemi veya geçici veya muhafaza tedbirleri elde etmek amacıyla devlet yargısına gitmesine, tahkim anlaşmasının varlığı bir engel teşkil etmez. Bunun için hakem mahkemesinin henüz teşekkül etmemiş olması gerekir ${ }^{75}$. Fransız Yargıtay’1 Danel c./Sté Sotiaf Informatique Kararı'nda bu özgürlüğü hükme bağlamıştır ${ }^{76}$. Tarafların hakem heyetinden de geçici hukuki koruma talep edebilirler; ancak hakem heyeti üçüncü kişileri bağlayıcı karar alamaz ve haciz kararı veremez ${ }^{77}$. Madde hükmü adli teminatlara ilişkin hükümleri saklı tutmuştur. Aynı uygulama Fransa'da 2011 öncesinde de vard1.

Uncitral Model Kanunu m. 17/(1) uyarınca da tarafların aksine anlaşmaları hariç, hakem mahkemesi, bir tarafın talebi üzerine geçici hukuki korumalara karar verebilir. Hakem heyeti tedbir için tarafın uygun bir güvence vermesini isteyebilir ${ }^{78}$. Hakem heyeti gerekli görürse, kendisine karşı geçici tedbir istenene haber vermeden geçici tedbire hükmedebilir ${ }^{79}$. Kanun'un m.17/J hükmüne göre hakem mahkemesinin varlı̆̆1, devlet mahkemesinden geçici tedbir istenmesine engel olmaz ${ }^{80}$.

TMTK m. 6 hükmü uyarınca da taraflar hakem heyeti yerine devlet mahkemesinden ihtiyati tedbir veya ihtiyati haciz talep edebilirler. Ancak tarafların bu talebi hakem heyetine yöneltmesi halinde, heyetin sınırlı bir yetkisi söz konusudur ${ }^{81}$. Hakem heyeti cebri icra organları tarafindan icrası ya da diğer resmi makamlar tarafından yerine getirilmesi gereken ihtiyati tedbir veya ihtiyati haciz kararı veremeyeceği gibi, üçüncü kişileri bağlayan ihtiyati tedbir veya ihtiyati haciz kararı da veremez.

\section{E.Uyuşmazlığın Esasına Uygulanacak Hukuk}

CPC m. 1511 uyarınca hakem heyeti, tarafların seçtiği hukuk kurallarına uygun olarak veya bu olmadığı takdirde, yararlı olduğunu takdir ettiği kurallara uygun olarak ihtilafi çözümler. Eski

\footnotetext{
${ }^{75}$ De Boisséson, s. 760, 761.

${ }^{76}$ De Boisséson, s. 759.

77 Özel, s. 114.

78 Özel, s. 111.

${ }^{79}$ Dayınlarlı, Uncitral, s. 172.

${ }^{80}$ Dayınlarlı, Uncitral, s. 172.

${ }^{81}$ Akıncı, s. 101.
} 
düzenlemede de m. 1496 hükmü aynıdı. Ancak m. 1511 hükmü "tüm hallerde ticari adetler dikkate alınır" ifadesi yer almamıştır ${ }^{82}$. Bu hususta da taraf iradeleri öncelikli ve üstün tutulmuştur ${ }^{83}$. Tarafların hukuk seçimi yapmamış olmaları halinde, hakem heyetinin uygulanacak hukuku belirlemesinde de hakemler tamamen serbesttirler ${ }^{84}$.

Hükümlerin ifadesinde "hukuk kuralları" (Fransızca "règles de droit" / İngilizce "rules of law") deyimi kullanılmıştır. Buna göre taraflar bir nasyonel hukuku seçebilirler, birden çok devlet hukukunu bir araya getirerek bir hukuk yaratabilirler ve buna hukukun genel ilkelerini ve uluslararasi ticaretin temel prensiplerini de ekleyebilirler ${ }^{85}$. Compania Valenciana de Cementos Portland SA c/ Primary Coal Inc. Kararı'nda Paris İstinaf Mahkemesi lex mercatorianın "hukuk kuralları" ifadesinin içinde yorumlanması gerektiği karara bağlamıştır ${ }^{86}$.

Uncitral Model Kanunu m 28/1'de de bu konudaki serbesti aynen düzenlenmiştir. Model Kanun'da da hukuk kuralları deyimi kullanılmıştır ve aynı şekilde yorumlanmaktadır. Buna göre taraflar bir uluslararası konvansiyondaki kuralları ya da uluslararası nitelikteki bir belgedeki hükümleri veya farklı ulusal hukuklarda yer alan kuralları ya da lex mercatoriayı veya akitlerle ilgili Unidroit Prensipleri'ni seçebilirler ${ }^{87}$. Hakem mahkemesi her halükarda sözleşme hükümlerine göre karar verir; ancak ihtilafa uygulanabilir olan örf ve adet kurallarını da dikkate almak zorundadır ${ }^{88}$.

Model Kanun hukuk seçimi prensibinde hakim olan temel ilkeyi tekrar ederek taraflar aksini belirtmedikçe hukuk seçiminin kanunlar ihtilafı kurallarını değil, maddi hukuk kurallarını kapsadığını ifade etmiştir ${ }^{89}$. Böylelikle atıf prensibi bertaraf edilmiştir. Taraflar uygulanacak hukuku tayin etmemişlerse hakem mahkemesi öncelikle tahkim yeri kanununa göre uygun olan kanunlar ihtilafı kurallarını araştırmalı; sonrada bu kuraldan itibaren uygulanacak hukuku belirlemelidir ${ }^{90}$. Tarafların hukuk seçimi hususunda tam bir serbestisi varken, hakemler kanunlar ihtilafı kuralları ile sınırlanmıştır ${ }^{91}$.

\footnotetext{
${ }^{82}$ Jarrosson / Pellerin, Rev. Arb., s. 66.

${ }^{83}$ Robert, s. 265.

${ }^{84}$ De Boisséson, s. 592.

${ }^{85}$ De Boisséson, s. 589; Robert, s. 266; Özel, s. 125, 126.

${ }^{86}$ Paris 1ere, 13.07.1989.

${ }^{87}$ Özel, s. 124, 125.

${ }^{88}$ Dayınlarl, Uncitral, s. 180.

89 Özel, s. 124.

${ }^{90}$ Dayınlarlı, Uncitral, s. 180.

${ }^{91}$ Dayınlarlı, Uncitral, s. 180.
} 
TMTK m. 12/C hükmü de uyuşmazlığın esasına uygulanacak hukuk konusunda taraf iradelerinin serbestisini hüküm altına almıştır ${ }^{92}$. Hakem heyeti ticari örf ve adetler ile ticari teamülleri de göz önüne alır $^{93}$. Belirli bir devletin hukukunun seçilmiş olması, aksi belirtilmedikçe, o devletin doğrudan doğruya maddi hukukunun seçilmiş olduğu anlamına gelir"94. TMTK'nda da "hukuk kuralları" ifadesinin kullanılmış olmasının da altını çizmek gerekir ${ }^{95}$. Tarafların hukuk seçimi yapmamış olmaları halinde, hakem veya hakem kurulu, uyuşmazlık ile en yakın bağlantı içinde sonucuna vardığı devletin maddi hukuk kurallarına göre karar verir ${ }^{96}$.

CPC m. 1512 ve eski düzenlemedeki m. 1497 hükmü uyarınca tarafların hakem heyetine böyle bir görev vermeleri halinde hakem heyeti uyuşmazlığı dostane aracı olarak çözebilir ${ }^{97}$. Bu hüküm de gerek Uncitral m. 28/3 düzenlemesiyle gerekse TMTK m. 12/C düzenlemesiyle uyumludur.

CPC'ye 2011 reformu ile eklenen yeni bir düzenleme olarak m. 1513 hükmü uyarınca, hakem mahkemesi taraflar aksini kararlaştırmamışlarsa oy çokluğu ile karar alır; çoğunluk sağlanamazsa hakem heyeti başkanı tek başına karar alabilir ${ }^{98}$. Başkanın tek başına karar alabilme yetkisi iç tahkim uygulamasında kabul edilmemiştir.

\section{V.Yabancı Ülkede veya Milletlerarası Tahkim Konusunda Verilmiş Olan Hakem Kararlarının Tanınması ve Tenfizi}

CPC m. 1514 hükmü ile iddia eden tarafindan varlığı ortaya konan hakem kararı, milletlerarası kamu düzenine açıkça aykırı değilse Fransa' da tanınır ve tenfiz edilir düzenlemesi getirilmiştir. $\mathrm{Bu}$ hüküm Fransız Hukuku'ndaki şartlı icra (provisional enforcement) hükmü olarak bilinmektedir $^{99}$. Eski düzenlemede de aynı ifadeler m. 1498 hükmünde yer alıyordu. Buna göre tanıma ve tenfizin iki temel şartı vardır: İlk olarak geçerli bir hakem kararı mevcut olmalı ve tenfiz

\footnotetext{
92 Özel, s. 127; Akıncl, s. 168.

${ }^{93}$ Akınci, s. 170.

94 Özel, s. 127.

95 Özel, s. 128.

${ }^{96}$ Akıncı, s. 171.

${ }^{97}$ De Boisséson, s. 593.

${ }^{98}$ Kleiman Elie, “France's New Arbitration Law About To Enter Into Force”, International Arbitration Law Rewiev, 2011, 14(3), s. 15, (I.A.L.R.).

${ }^{99}$ Lin Yu / Ahmed, I.A.L.R., s. 26.
} 
talep eden taraf bunu ispatlamalı, ikinci olarak da bu karar milletlerarası kamu düzenine açıkça aykırı olmamalıdır ${ }^{100}$.

Önceki uygulamada hakem kararının iptalinin dava edilmesi ya da karar karşı yapılan herhangi bir başvuru, kararın icrasını kendiliğinden askıya alıyordu; ancak m. 1526 hükmü bunu değiştirdi ${ }^{101}$. Buna göre hakem kararına itiraz edilmesi, kararın icrasını kendiliğinden durdurmaz ${ }^{102}$.

CPC m. 1516 hükmü ile de eskisinde olduğu gibi tanıma ve tenfizde görevli mahkeme Paris İstinaf Mahkemesi'dir. Hükmün altında yatan amaç, Paris'in bir tahkim merkezi olarak konumunu korumak ve güçlendirmektir ${ }^{103}$.

Fransa'da verilen milletlerarası hakem kararlarının tanınması veya tenfizi milletlerarası kamu düzenine aykırı ise iptal edilebilir düzenlemesini getiren m. 1520 hükmü "açıkça aykırılı̆̆ı" aramamıştır. Benzer durum eski Kanun'daki m. 1502/5 düzenlemesinde de yer alıyordu ${ }^{104}$. Fransız mahkemesi tanıma veya tenfiz kararını verirken sadece hakem kararının milletlerarası kamu düzenine aykırı olup olmadığını inceleyecek, hakem kararının esasını inceleyemeyecektir; çünkü tarafların esasa uygulanacak hukuku başka bir hukuk olarak seçmiş olma imkanları vardır ${ }^{105}$.

Fransız Kanunu'nda tenfiz talebinin reddi sebebi olarak sadece milletlerarası kamu düzenine aykırılık gösterilmiş; özellikle red sebeplerini sayan bir hükme yer verilmemiştir. Fransa Yabancı Hakem Kararlarının Tanınması Ve Tenfizine İlişkin New York Konvansiyonu'na taraf olan devletlerden olduğundan, bu Konvansiyon'da sayılan red sebepleri Fransa'da da uygulanacaktır.

Konvansiyon'un 5. Maddesi'nde özetle; taraflar ehliyetsizse, tahkim sözleşmesi geçersizse, kendisine karşı hakem kararı ileri sürülen tarafa gereği gibi bilgi ve savunma imkanı verilmemişse, hakem mahkemesinin oluşması veya tahkim usulü tahkim sözleşmesine uygun değilse, hakem kararı taraflar için henüz zorlayıcı hale gelmemişse veya verildiği ülkenin yetkili makamınca iptal edilmiş veya askıya alınmışsa, ihtilafın esasının tenfiz devletinin kanunlarına uygun olarak tahkim yoluyla çözülemeyeceği veya hakem kararının tanınması ve tenfizinin tenfiz devletinin kamu

\footnotetext{
${ }^{100}$ Robert, s. 284; Jarrosson / Pellerin, Rev. Arb., s. 68; Lin Yu / Ahmed, I.A.L.R., s. 26.

101 Kleiman, s. 16.

${ }^{102}$ Lin Yu / Ahmed, I.A.L.R., s. 27.

${ }^{103}$ Gaillard / De Lapase, s. 187.

${ }^{104}$ Dayınlarlı, Kamu Düzeni, s. 132.

105 Dayınlarlı, Kamu Düzeni, s. 132.
} 
düzenine aykırıysa gibi sebepler sayılmıştır. Uncitral Model Kanunu m. 36 hükmü de benzer şekilde red sebeplerini düzenlemiştir ${ }^{106}$.

TMTK'da tanıma ve tenfiz hususu düzenlenmemiştir. Türkiye de New York Konvansiyonu'na taraf devletlerdendir. Yabancı bir hakem kararı, Konvansiyonun kapsamına giriyorsa buna göre tenfiz edilecek; aksi halde MÖHUK hükümlerine göre tenfiz edilecektir ${ }^{107}$. New York Konvansiyonu bu hususta özel kanun niteliğinde olmakla birlikte, MÖHUK da sonraki kanun durumundadır. Ancak MÖHUK m. 1 uyarınca yabancılık unsuru bulunan özel hukuk ilişkilerine bu Kanun hükümleri uygulanacaktır derken sonraki cümlede milletlerarası sözleşme hükümlerini saklı tutmuştur.

\section{VI.Başvuru Yolları}

Başvuru yolları açısından Fransa'da verilen hakem kararları ve yabancı ülkede verilen hakem kararları şeklinde ikili bir ayrıma gidilmiştir.

\section{A.Fransa'da Verilen Hakem Kararları}

CPC m. 1518 uyarınca, milletlerarası tahkim konusunda Fransa'da verilen hakem kararı sadece iptal müracaatına konu edilebilir ${ }^{108}$. Benzer düzenleme eski CPC m. 1504 hükmünde yer almaktadır $^{109}$.

CPC m. 1520 hükmünde iptal sebepleri sınırlı olarak sayılmıştır ${ }^{110}$. Buna göre;

1) Hakem mahkemesi haksız olarak yetkili veya yetkisiz olduğunu beyan ederse veya,

2) Hakem mahkemesi usulsüz olarak kurulmuş ise veya,

3) Hakem mahkemesi kendisine tevdi edilen göreve uymaksızın karar verdiyse veya,

\footnotetext{
106 Dayınlarlı, Arbitration, s. 120.

107 Akinci, s. 249, 250.

108 Jarrosson / Pellerin, Rev. Arb., s. 70; Gaillard / De Lapase, s. 187.

${ }^{109}$ De Boisséson, s. 820, 821; Robert, s. 306.

${ }^{110}$ Gaillard / De Lapase, s. 187.
} 
4) İtiraz ilkesine uyulmamışsa veya,

5) Hakem kararının tanınması veya tenfizi milletlerarası kamu düzenine aykırı ise Hakem kararının iptali talep edilebilir.

Eski düzenlemede de m. 1502 hükmünde Fransa'da verilen hakem kararları için iptal sebepleri sınırlı olarak sayılmıştır. Bunlar aynı zamanda tanımayı veya tenfizi kabul eden kararın istinafı sebepleridir.

CPC m. 1522 uyarınca özel anlaşma ile taraflar, her an iptal müracaatından açıkça vazgeçebilirler ${ }^{111}$. Bu hüküm uluslararası tahkime Fransız Hukuku'nun uygulanması seçilmiş olmasa bile tahkim yerinin Fransa olarak seçilmesini teşvik amacı gütmektedir ${ }^{112}$. Tarafların seçecekleri hukukta asgari ve dengeli bir kontrol mekanizmasının bulunmasını tercih edecekleri düşünülmektedir ${ }^{113}$.

Fransa'da verilen milletlerarası bir hakem kararının tanınması veya tenfizini reddeden karara karşı m. 1523 uyarınca istinaf müracaatı yapılabilir.

\section{B. Yabancı Ülkede Verilen Hakem Kararları ve Ortak Düzenlemeler}

Yabancı ülkede verilen hakem kararlarına ilişkin m. 1525 düzenlemesi ise şöyledir: Yabancı ülkede verilen bir hakem kararının tanınması veya tenfizi talebine dair verilen karar, istinaf edilebilir ${ }^{114}$. Eski uygulamada da m. 1501 uyarınca yabancı ülkede alınan hakem kararını tanıma veya tenfizi reddeden karar istinaf edilebiliyordu ${ }^{115}$. Eski CPC m. 1502 hükmünde sınırlı sayıda sayılan sebeplere dayanılarak, yabancı ülkede alınan hakem kararlarını tanıma veya tenfizi kabule iilişkin karar da istinaf edilebiliyordu; ancak Fransa'da alınan hakem kararının tenfizine izin veren karara karşı müracaat yolu kapalıyd $1^{116}$.

\footnotetext{
${ }^{111}$ Lin Yu / Ahmed, I.A.L.R., s. 28, 29.

112 Jarrosson / Pellerin, Rev. Arb., s. 71.

113 Jarrosson / Pellerin, Rev. Arb., s. 71.

${ }^{114}$ Jarrosson / Pellerin, Rev. Arb., s. 73;

115 De Boisséson, s. 818; Robert, s. 294; Gaillard / De Lapase, s. 187.

${ }^{116}$ De Boisséson, s. 819; Robert, s. 295.
} 
CPC m. 1526 ortak hükmü uyarınca, hakem kararına karşı yapılan iptal müracaatı ve tenfizi kabul eden talimatnameye karşı istinaf müracaatı yapılması, kararın icrasını kendiliğinden durdurmaz ${ }^{117}$. Önceki düzenlemede iptal ve istinaf müracaatları, hakem kararının icrasını askıya alıyordu ${ }^{118}$.

Model Kanun da m.34 hükmünde hakem kararlarına karşı tek müracaat yolu olarak iptali düzenlemiştir ${ }^{119}$. TMTK m. 15 hükmü de aynı şekildedir ${ }^{120}$. Her iki Kanun'da da iptal davasının açıldığı devlet bakımından tahkime elverişsizlik ve kamu düzenine aykırılık mahkemece re'sen dikkate alınması gereken iptal sebepleridir ${ }^{121}$.

\section{Sonuç}

Birçok yazara göre Fransız Tahkim Kanunu mevcut haliyle bile oldukça iyi işliyordu ve Paris hala bir tahkim merkezi olmayı hak ediyordu. 2011 reformu ile Fransız Kanunu'nun temel liberal yapısı korunmuş olmakla birlikte, Fransız Yargıtayı'nın daha da liberal bakış açıları geliştirdiği Kararları'ndaki yeni ilkelere bu Kanun'da yer verilmemiştir. Özellikle Putrabali Kararı'nda yabancı hakem kararlarının tenfizinin önündeki neredeyse tüm engeller kaldırılmışıtır.

Bunlardan başka tahkim sözleşmesine ve tenfize ilişkin hükümler yumuşatılmış ve tahkim yargısı güçlendirilmiştir. Destek hakimi düzenlemesiyle Fransız hakimine ayrı bir yer tahsis edilmiştir.

Neticede Fransız Tahkim Kanunu bu reformla hem otuz yıl sonra güncellenmiş hem de yabancı uygulamacılar için daha anlaşılır bir hale gelmiştir. Böylece yatırımcıların nezdindeki cazibesini koruyacaktır.

\footnotetext{
${ }^{117}$ Jarrosson / Pellerin, Rev. Arb., s. 74, 75.

${ }^{118}$ De Boisséson, s. 822.

${ }^{119}$ Dayınlarlı, Uncitral, s. 184-186.

${ }^{120}$ Akincl, s. 191.

${ }^{121}$ Akıncl, s. 201.
} 


\section{Kaynakça}

Akıncı, Z. (2021). Milletlerarası Tahkim, 6. Baskı, Vedat Yayınevi, İstanbul.

Dayınlarlı, K. (2010). International Arbitration, Dayınlarlı Yayınları, Ankara.

Dayınlarlı, K. (2011). Milli-Milletlerarası Kamu Düzeni Tahkime Etkileri Ve Sonuçları, 2. Baskı, Dayınlarlı Yayınları, Ankara.

Dayınlarlı, K. (2012). UNCITRAL Kurallarına Göre Uzlaşma Ve Tahkim, 3. Baskı, Dayınlarlı Hukuk Yayınları, Ankara.

De Boisséson, M. (1990). Le Droit Français De L’Arbitrage Interne Et International, GLNÉditions.

Fortier, L. Y. (2011). “La Nouvelle Loi Française Sur L’Arbitrage: Vues D’Outre Atlantique”, Fransız Tahkim Kurumu (Association Française D’Arbitrage) Yıllık Konferansı Tebliğ Metni, Paris.

Gaillard, E. (2007). “La Jurisprudence De La Cour De Cassation En Matière D’Arbitrage International”, Fransız Yargıtayı'na Sunulan Tebliğ Metni, Paris.

Gaillard, E. / De Lapasse, P. (2011). “Le Nouveau Droit Français De L’Arbitrage Interne Et International", Etudes Et Commentaires Chroniques / Arbitrage, Recueil Dalloz, Numéro 3.

Guinchard, S. / Ferrand, F. (2006). Procédure Civil, 28e Édition, Dalloz, Paris.

Jarrosson, C. / Pellerin, J. (2011). “Le Droit Français De L’Arbitrage Aprés Le Décret Du 13 Janvier 2011”, Revue De L’Arbitrage, S. 1.

Kleiman, E. (2011). “France's New Arbitration Law About To Enter Into Force”, International Arbitration Law Rewiev, 14(3).

Lin Yu, H. (2013). “Written Arbitration Agreements-What Written Arbitration Agreement?”, Civil Justice Quarterly, 32(1).

Lin Yu, H. / Ahmed, M. (2012). “The New French Arbitration Law: An Analysis”, International Arbitration Law Rewiev, 2012. 
Özel, S. (2008). Milletlerarası Ticari Tahkimde Kanunlar İhtilafı Meseleleri, 1. Baskı, Legal Yayınevi, İstanbul.

Poudret, J. F. (2004). “L'Originalité de Droit Français De L'Arbitrage Au Regard Du Droit Comparé", Revue Internationale De Droit Comparé, Volume 56, Numéro 1.

Robert, J. (1993). L’Arbitrage, 6. Bask1, Éditions Dalloz, Paris.

www.legifrance.gouv.fr, 15.10 .2021

http://www.uncitral.org/pdf/french/texts/arbitration/ml-arb/07-86999_Ebook.pdf, 15.10.2021.

http://www.uncitral.org/pdf/french/texts/arbitration/NY-conv/XXII_1_f.pdf, 15.10.2021. 